\title{
Mapping Research in Teacher Education on Diversities and Inequalities: Opening Possibilities Through Social Cartography
}

\author{
Jeannie Kerr \\ The University of Winnipeg \\ je.kerr@uwinnipeg.ca \\ Vanessa Andreotti \\ University of British Columbia \\ vanessa.andreotti@ubc.a
}

\begin{abstract}
This article considers the potential of the methodology of social cartography to open generative possibilities in research on diversities and inequalities in teacher education in the international context. Research in teacher education focusing on difference or diversities and inequalities offers highly diverse practices and orientations, yet we have found that intelligibility across research communities can be challenging and ultimately limiting for the field. Social cartography is a methodology that attempts to address this issue, inviting researchers and practitioners to create forms of conversation that are more tentative, self-critical, and generative. In this article, we introduce our priorities in teacher education that center awareness of social-cultural commitments and assumptions, as well as historical context. We then share a social cartography of teacher education research we have created to reveal the possibilities of social cartography for teacher education, as well as an invitation to open needed dialogue amongst teacher education researchers and practitioners.
\end{abstract}

\section{Introduction}

This article focuses on different perspectives and approaches to research and practice in teacher education, and the potential use of social cartography to engage more generatively within the field. In this article, we introduce our priorities for research in teacher education that reflects awareness of social-cultural commitments and assumptions, as well as historical context, to enable generative dialogue across research communities. From these priorities, we discuss our interpretation of the methodology of social cartography based on the work of Rolland Paulston $(2000 ; 2009)$ that provides tools to enable shared vocabularies that can open up the potential for deeper dialogue across different paradigms of thought and practice. Drawing on this methodology, we share our social cartography of teacher education research focused on diversities and inequalities. This social cartography was developed through an historic and socialcultural lens. This particular lens to the research relies on an analysis of teacher education by Anne Phelan (2011), as well as insights from a summary of a comprehensive review of teacher education research by Marilyn Cochran-Smith and Ana Maria Villegas (2015). Our brief elaboration of our own research studies in teacher education are shared for the 
purposes of highlighting social cartography's potential use as a methodology that may facilitate greater understanding of research in the field of teacher education.

\section{Generative Possibilities for Teacher Education Research through Social Cartography}

In our work as researchers and practitioners, we believe that, given our modern socialization, we tend to assume the intelligibility and universality of our ontoepistemological assumptions, often forgetting the social, cultural and historical embeddedness of these assumptions. This fosters a form of epistemic competition where we can become positioned to seek affirmation and validation of our positions. Under these circumstances, we tend to avoid looking carefully at conflicts and differences in standards between different intellectual orientations and to evade examining the limits, paradoxes and contradictions of our own frames of reference. Social cartography is a methodology that attempts to address this issue; inviting us to create different forms of conversations through bringing together different traditions of thought in ways that are more tentative, self-critical, accountable, generous and generative. We have been exploring the potential of social cartography pedagogically within our work as educators and researchers in teacher education (Amsler, Kerr \& Andreotti, 2020; Kerr \& Andreotti, 2018; 2019) and educational studies (Andreotti, 2015; Andreotti et. al., 2016; Suša \& de Oliveira Andreotti, 2019), as well as through Vanessa's leadership in the Gestures Towards Decolonial Futures Collective that draws together researchers, artists, activists and Indigenous knowledge keepers (see https://decolonialfutures.net).

We have found that social cartography offers provisional and transitional frames of thinking in the form of visual narratives that emphasize the importance of depth, the ethical imperative to engage with dissent, and the creative potential of dissensus that respects the integrity of different ways of seeing, knowing and being in the world. It highlights intersections and tensions between intellectual communities inviting readers to sit with difficult cross-roads, to trace origins and implications of perspectives and to open up possibilities for different narratives in relation to the cartography itself and their own practices. Different from heuristics that attempt to offer a universal, normative and objective description of reality, social cartographies are pedagogical and non-normative. They work like a strategic map that amplifies the points/landmarks where conversations usually get stuck. They are designed to help us to trace historical and systemic processes, to draw attention to points of tension and complicated dynamics, and to draw connections to those aspects that are often disconnected or left conveniently hidden. Our experiences engaging with social cartography have encouraged us to consider the potential of this methodology in the field of research in teacher education that addresses difference and inequalities. We believe social cartography has the potential to address the disconnections we have observed between research communities in teacher education that emerge from differing theoretical and ideological commitments that influence the social-cultural practices of researchers.

\section{Our Research and Theoretical Frameworks in Teacher Education}

Journal of Contemporary Issues in Education, 2020, 15(2), pp. 69-84. (c) Author(s), Creative Commons Attribution 4.0 (CC BY 4.0) licence http://ejournals.library.ualberta.ca/index.php/JCIE

doi 10.20355/jcie29423 
Our research in initial teacher education is focused on matters of diversities and social inequalities and how these matters may be understood and addressed within programs of teacher education. Our work is motivated by critiques within postcolonial, decolonial and Indigenous studies that highlight the ethnocentric and paternalistic assumptions that undergird discourses in society and manifest in social spaces and in educational contexts. Drawing on the ideas of such scholars as Walter Mignolo, Ramón Grosfoguel, Gaytri Spivak, Dwayne Donald and Sunera Thobani, we similarly believe that efforts to make a difference and search for simple solutions often results in ethnocentric and paternalistic approaches in education that are driven by desires for the affirmation of our benevolence and the re-centering of our subjectivities as saviors or enablers of change in educational contexts.

Based on the work of these noted theorists, and our own experiences as researchers and practitioners in teacher education, we argue that as an academic field we have been collectively over-socialized in Euro-Western cultural assumptions and narratives, into a single story of progress, development and human evolution. This single story has been normalized and naturalized through all modern institutions, and establishes social and cultural hierarchies that are extremely difficult to interrupt because they are reproduced in a systemic way. Even when we see ourselves outside of it, we are still within because the single story structures not only our thinking, but also our desires, perceived entitlements and securities. In this sense, there is a complex and implicit conflict of interest in the attempt to change structures of injustice when we benefit from the injustices we seek to change. In the imposed single story, our perceptions of ourselves are also dependent on our perceptions of others: our positionalities are relationally constructed (Bhabha, 1994). Therefore, in order to see ourselves as benevolent knowledgeable leaders moving ahead in time, towards a single ideal of progress, we necessarily need others who are perceived to be backward, lacking knowledge/education, lagging behind, and waiting for us as leaders they can follow. The perception of the other as lacking is necessary to justify our perceived entitlement as dispensers of knowledge of universal worth. In this context, engagements and representations between asymmetric communities tend to follow problematic patterns. Within our research and work in teacher education, we engage HEADS-UP graphics as social cartographies that helps us consider the ways inequalities manifest in educational contexts and relationships (Andreotti \& Pashby, 2013). We share the HEADS-UP cartography as an illustrative example of a way we have engaged our complex theoretical commitments through social cartography in our pedagogical work in teacher education.

HEADS UP Patterns and questions in attempts to represent and engage with non-dominant communities

\begin{tabular}{|l|l|l|}
\hline $\begin{array}{l}\text { Historical pattern of } \\
\text { engagement and } \\
\text { representation }\end{array}$ & $\begin{array}{l}\text { Whose idea of development/ } \\
\text { education / the way } \\
\text { forward? }\end{array}$ & $\begin{array}{l}\text { Whose template for knowledge } \\
\text { production? }\end{array}$ \\
\hline
\end{tabular}

Journal of Contemporary Issues in Education, 2020, 15(2), pp. 69-84. 


\begin{tabular}{|c|c|c|}
\hline $\begin{array}{l}\text { Hegemony } \\
\text { (promoting a single } \\
\text { story of progress) }\end{array}$ & $\begin{array}{l}\text { What assumptions inform } \\
\text { what is perceived as real and } \\
\text { ideal in this context? }\end{array}$ & $\begin{array}{l}\text { Whose knowledge is perceived to } \\
\text { have universal value? How come? } \\
\text { How can this imbalance be } \\
\text { addressed? }\end{array}$ \\
\hline $\begin{array}{l}\text { Ethnocentrism } \\
\text { (projecting the views of } \\
\text { one group as universal) }\end{array}$ & $\begin{array}{l}\text { What is being presumed to be } \\
\text { normal, good, moral, natural } \\
\text { or desirable? Where do these } \\
\text { assumptions come from? }\end{array}$ & $\begin{array}{l}\text { How is dissent addressed? How are } \\
\text { dissenting groups framed and } \\
\text { engaged with? }\end{array}$ \\
\hline $\begin{array}{l}\text { Ahistoricism (forgetting } \\
\text { historical legacies and } \\
\text { complicities) }\end{array}$ & $\begin{array}{l}\text { How is history, and its } \\
\text { ongoing effects on social/ } \\
\text { political/economic relations, } \\
\text { addressed (or not) in the } \\
\text { formulation of problems and } \\
\text { solutions? }\end{array}$ & $\begin{array}{l}\text { How is the historical connection } \\
\text { between dispensers and receivers of } \\
\text { knowledge framed and addressed? }\end{array}$ \\
\hline $\begin{array}{l}\text { Depoliticization } \\
\text { (disregarding power } \\
\text { inequalities and } \\
\text { ideological roots of } \\
\text { analyses and proposals) }\end{array}$ & $\begin{array}{l}\text { What analysis of power } \\
\text { relations has been performed? } \\
\text { Are power imbalances } \\
\text { recognized, and if so, how are } \\
\text { they either critiqued or } \\
\text { rationalized? How are they } \\
\text { addressed? }\end{array}$ & $\begin{array}{l}\text { Do educators and students } \\
\text { recognize themselves as culturally } \\
\text { situated, ideologically motivated } \\
\text { and potentially incapable of } \\
\text { grasping important alternative } \\
\text { views? }\end{array}$ \\
\hline $\begin{array}{l}\text { Self-congratulatory, } \\
\text { Self-serving and } \\
\text { salvationist attitude } \\
\text { (oriented towards self- } \\
\text { affirmation /CV } \\
\text { building /white savior) }\end{array}$ & $\begin{array}{l}\text { How are marginalized peoples } \\
\text { represented? How are those } \\
\text { who intervene represented? } \\
\text { How is the relationship } \\
\text { between these groups } \\
\text { represented? "Who" is this } \\
\text { really about? }\end{array}$ & $\begin{array}{l}\text { Do individuals recognize } \\
\text { themselves as part of the problem? } \\
\text { Who is exalted by the resource? } \\
\text { Who benefits from this exaltation? }\end{array}$ \\
\hline $\begin{array}{l}\text { Un-complicated } \\
\text { solutions (ignoring the } \\
\text { complexity of } \\
\text { epistemological, and } \\
\text { ontological dominance) }\end{array}$ & $\begin{array}{l}\text { Has the urge to 'make a } \\
\text { difference' weighted more in } \\
\text { decisions than critical } \\
\text { systemic thinking about the } \\
\text { problem and unexpected } \\
\text { effects of the solutions } \\
\text { proposed? }\end{array}$ & $\begin{array}{l}\text { Are simplistic analyses offered and } \\
\text { answered in ways that do not invite } \\
\text { people to engage with complexity } \\
\text { or recognize complicity in systemic } \\
\text { harm? }\end{array}$ \\
\hline $\begin{array}{l}\text { Paternalism (seeking } \\
\text { affirmation of } \\
\text { superiority through the } \\
\text { provision of help) }\end{array}$ & $\begin{array}{l}\text { How are those at the receiving } \\
\text { end of this initiative expected } \\
\text { to respond to the 'help' they } \\
\text { receive? }\end{array}$ & $\begin{array}{l}\text { Does this initiative promote the } \\
\text { symmetry of less powerful groups } \\
\text { and recognize these groups' } \\
\text { legitimate right to disagree with the } \\
\text { formulation of problems and } \\
\text { solutions proposed? }\end{array}$ \\
\hline
\end{tabular}

The theories underlying the HEADS-UP social cartography are focused on the need for intellectual accountability and genuine relational openness in our research processes and 
commitments (Andreotti, 2016). In terms of intellectual accountability, they call for more nuanced understandings of our own positionality and systemic complicity in the reproduction of inequalities. They emphasize the need for us to engage with our foreclosures: what we need to forget in order to continue to believe what we want to believe in. They ask us to use reason to explore the limits of reason itself. In this sense, they point to the need for genuine relational openness in sensing and relating to the world differently, beyond Cartesian boxes, through bodies, lands, and spirits. These visceral relationships combine a commitment to both political and existential forms of responsibility, where relationships are not mediated by identities, knowledge, or understanding, and where we are not left off the hook in terms of our complicity in harm and political responsibilities.

We have used these insights to both design and develop teacher education practices and research projects that engage with the complexities of social inequalities in education and our positionalities in relation thereto (Kerr \& Andreotti, 2018; 2019). When presenting our research and findings at conferences, we have noticed that intelligibility amongst researchers in teacher education can be difficult. Although this is not always the case, we have often experienced responses that reject our results precisely because they do not fit what is expected. Because we have not found positive results that attest to the improvement of common social justice orientations, we have been told that we need to fix what we do in order to make it work.

In the professional discipline of teacher education, we would argue that the dominant focus on best practices has limited our ability as a discipline to engage with difficult knowledge, to learn from failure, and to face divergent interpretations and paradoxes in our field. As we tend to instrumentalize results to fit desired improvements, we close possibilities for deeper and more nuanced understandings, and for genuinely new possibilities of practice. This scenario is made worse by the limited engagement we have with other disciplines where different discussions about the nature of our relationships with each other are taking place. We believe engaging social cartographies emphasizing the theories and ideologies informing teacher education research may help us to start these different kinds of conversations within the practices of teacher education research. In this way, we can put our desires to fix and to solve to the side, and instead create spaces that forefront unexamined or naturalized assumptions and commitments within research communities, and relate to the socio-cultural dimension of the research itself.

\section{Engaging Social Cartography Methodology}

Our interest in supporting dialogue across research communities in teacher education through social cartography emerges from experiences of foreclosures and disconnections in discussing our work within teacher education, and our appreciation for what we have experienced in engaging this methodology. We see social cartography as opening up expansive conversations and intelligibility of research across difference. In this article, we are engaging with Paulston's work on social cartographies, complemented by Anne Phelan's historical analysis of the field of teacher education, as well as Marilyn Cochran- 
Smith and Ana Maria Villegas' summary and critical analysis of a large review of teacher education research to inform the priorities and development of our social cartography of teacher education. In this way, we are moving from engaging social cartographies in teacher education and research, to building a provisional social cartography of teacher education research.

Paulston's social cartography methodology can offer the resources to create a provisional visual map of the field that draws the edges of assumptions, commitments, agreements and distinctions that emerge through teacher education research as a social practice. Paulston's work emerges from an appreciation of the diversity of paradigms of thought and practice within fields of inquiry, and is focused on non-propositional forms of representation that encourages "openness to a resonance or nexus of relations" amongst diverse orientations (Paulston \& Liebman, 1994, p. 217). As Rust and Kenderes (2011) note, Paulston's work is unique in that it offers the ability to open diverse dialogue across paradigms of thought; provides opportunities to show complexity of diverse understandings through visual dimensionality of perspectives and movement; and creates opportunities for inclusiveness through expansiveness of the map itself (pp. 25-28). The desire in social cartography, as Paulston develops it, is to "open up meanings, to uncover limits within cultural fields, to highlight reactionary attempts to seal borders and prohibit translations" (Paulston, 2009, p. 977), and to provide a heuristic device to enable communication across difference (Paulston, 2000). We believe that our social cartography will allow for multiplicity and partiality of positions to be visible and our position "to be acknowledged without compromising conviction or imposing a demand for immediate consensus" (Andreotti, 2015, p. 200).

Relying on Paulston's methodology, our social cartography of teacher education research focused on diversities and inequalities is not provided as a static representation. This cartography is offered as a tool that is mapping the imaginaries of the field in which our research is located, as well as an invitation to others to engage in remapping the borders and understanding relations between teacher education researchers. We are not sharing a polished graphic that enshrines our views. Instead, we share our ongoing draft cartography for engagement with others. We invite our peers to use the cartography to expand and redraw it, and perhaps engage pedagogically with us, and communities beyond. The collective pedagogical value is in using the mapping to disrupt unquestioned common understandings and open up space to generate new ideas and remap borders, and add to the opportunities of intelligibility amongst researchers in teacher education whose research and practice is similarly focused on diversities and inequalities in education.

\section{Building the Cartography - Phelan's Analysis of Teacher Education}

The cartography itself is constructed on our understandings of theory and practice in research quite generally, and teacher education quite specifically. We rely on Anne Phelan's (2011) historical analysis of the field of teacher education to further develop the socio-cultural aspect of the map, as well as the large research review of teacher education from a socio-historical perspective by Cochran-Smith and Villegas (2015). Phelan's

Journal of Contemporary Issues in Education, 2020, 15(2), pp. 69-84. (c) Author(s), Creative Commons Attribution 4.0 (CC BY 4.0) licence 
analysis is developed within a broader concern that teacher education research has been situated as playing a 'practical role' and argues that this focus has resulted in various kinds of parochialism that confine the purpose and promise of inquiry in the field (Phelan, 2011, p. 208). As a specific area in itself, teacher education research literature is shown to emanate from the United States, Britain, Canada and Australia from the last half of the $20^{\text {th }}$ Century. Phelan shares the following time periods that reflect dominant attention to specific orientations, methods and questions drawing on a number of researchers/scholars. What follows is our synthesis of Phelan's analysis:

1950 s to $1980 \mathrm{~s}$

Orientation: $\quad$ Teacher Education as a Training Problem

Key Question: How do we produce effective behaviors in prospective teachers so that program and policy decisions can be empirically based?

Methodology: $\quad$ An empirical science of teacher education to identify interventions to apply to a range of contexts to effect desired outcomes. Instrumental and technical-rational focus in methodology

1980 s to 2000 s

Orientation: $\quad$ Teacher Education as a Learning Problem

Key

Question:

What should teachers learn and be able to do?

Change:

Methodology:

Shift from 'teacher behaviour' to 'teacher thinking' about practice Interpretative/hermeneutical/qualitative methodologies aimed to inform work of teacher educators in teacher education. Collaborative and self-study research practices driven by the concerns of the researcher/institution to solve practical problems

Mid to Late 1990s to Present

Orientation: $\quad$ Teacher Education as a Policy Problem

Key

Question:

Does teacher education make a difference to student learning in

Change: schools?

Shifting to policy as the key focus motivated by the need to justify teacher education as being legitimately housed in universities 
Methodology:

Focus on program effectiveness leads to a return to social science methodologies and instrumental and technical research practice

(Phelan, 2011, pp. 209-21)

Phelan (2011) places her own work in a fourth phase focused on understanding, and aligns with what she portrays as a smaller group of researchers that consider teacher education as a cultural object that could be understood inter-disciplinarily. She frames this small group as working within and between fields of philosophy, history, sociology and politics around concerns emerging from teacher education. Phelan characterizes this research as attending to subjectivities of people in contexts of responsibility in conditions that they have not made, and a related focus on the discursive productions of teacher identities, school practices and social values. From this perspective, the questions raised do not lend themselves to answers but to understanding, and specifically avoids prescriptions for practice. Phelan attends to the significance of this research as a retreat from an instrumental and "consequence-oriented" research focus, where practitioners can engage with such research and then return to practice "prepared to complicate, critique and converse in expansive ways" (p. 217).

\section{Building the Cartography - Cochran-Smith and Villegas' Review of Teacher Education Research}

The review by Cochran-Smith and Villegas (2015) shows similar concerns and patterns as Phelan, but offers a much larger and detailed engagement with mainstream teacher education research, as well as a more specific link to the political/societal context as influencing research trends in teacher education that have emerged. The trends are identified as emerging from the movement in high income countries, such as the US and Canada and Western European countries, from an industrial economy to a knowledgebased economy and an accompanying dominant neo-liberal economics ideology in educational policy and practice. The noted trends are presented as: 1) unprecedented attention to teacher quality and accountability; 2) changing conceptions of how people learn and what they need to know; and 3) an increasingly diverse student population due to immigration and growing school inequality (Cochran-Smith \& Villegas, 2015, p. 9). They note that the trends have normalized and naturalized discourses of outcomes while also framing teaching as complex intellectual work. Interestingly, the reviewers argue that the prominence of concern over the growing gap in educational outcomes between white and racialized students, has led to a current backlash against multi-cultural and social justice approaches to teaching and teacher education. The authors argue that this backlash has encouraged an increasing pressure to "concentrate on aspects of teacher preparation directly linked to test scores" (p. 10). We see these trends in line with Phelan's (2011) argument that the current policy focus in teacher education research is digressing to outcomes-based social-scientific research in an attempt to justify universities as being able to do the work required to close these gaps. We see both of 
these trends as related to the larger neo-liberal context influenced by global capitalism in which education is currently immersed.

While noting the significance of research as a social practice within their analytic frame, Cochran-Smith and Villegas (2015) and Cochran-Smith et al. ${ }^{1}$ (2015) also categorized research in teacher education based on the interests of researchers rather than ideological research paradigms. They sorted the clusters into A) teacher preparation accountability, effectiveness and policies; B) teacher preparation for the knowledge society; and C) teacher preparation for diversity and equity. This is interesting for our cartography, as we then began to see ourselves as immersed in cluster $\mathrm{C}$, yet concerned with A and $\mathrm{B}$. While we see the potential insights of understanding the social reasons behind the specific interests of researchers, we also feel broader clusters based on underlying assumptions and commitments enable the potential for greater understanding between researchers with common interests yet working in very different ideological paradigms. This became clear to us as our own research studies and commitments ideologically recognize the impossibilities in research focused on achieving equity, and hence we are focused on understanding the intersections between difference and inequalities. Thus, even the naming of the cluster as diversity and equity provided traces of the authors' ideological commitments that were naturalized. As a result of engaging with this work, we feel that our potential contribution is in providing a social cartography of teacher education research that maps the specific cluster in teacher education research related to difference or diversities and inequalities from an ideological orientation.

\section{Our Provisional Social Cartography of Research in Teacher Education on Diversities and Inequalities}

Informed by Phelan's and Cochrane-Smith and Villegas' work, and yet extending and reframing the categories and formations based on our own experiences and affiliations, we have developed our provisional cartography of teacher education research in diversities and inequalities that puts our work on the map. In our own work we are moving away from using the word diversities to the word difference, but use diversities here to support intelligibility across research paradigms. The map itself is oriented on two major dimensions: consequence and improvement-oriented research and understandingoriented research. Within each of these dimensions, there are again two distinctions within: the first distinguishes between process-product research and praxis research, the second distinguishes between Western, discursive informed research and transcultural, decolonial informed research. Additionally, specific theorists in each area are noted that we feel align with certain orientations and can assist in locating one's own theoretical commitments on the map. We have included some fairly high-profile educational

\footnotetext{
${ }^{1}$ Note that the original article "Framing teacher preparation research" was broken into two articles and both published in the same journal and same year. Thus far we have been citing from the first article. This reference takes up the second article, which continued with Cochran-Smith as 1st author, and Villegas as $2^{\text {nd }}$, but also introduced four additional researchers and an interesting title change: "Critiquing teacher preparation research: An overview of the field, Part II".

Journal of Contemporary Issues in Education, 2020, 15(2), pp. 69-84.

(c) Author(s), Creative Commons Attribution 4.0 (CC BY 4.0) licence

http://ejournals.library.ualberta.ca/index.php/JCIE

doi 10.20355/jcie29423 
theorists and researchers as a guide to highlight specific affiliations. We have also engaged in shading which is meant to illuminate current power and prominence being afforded in the field: shaded areas representing less prominence, and unshaded areas, being more visible, representing more powerful presence.

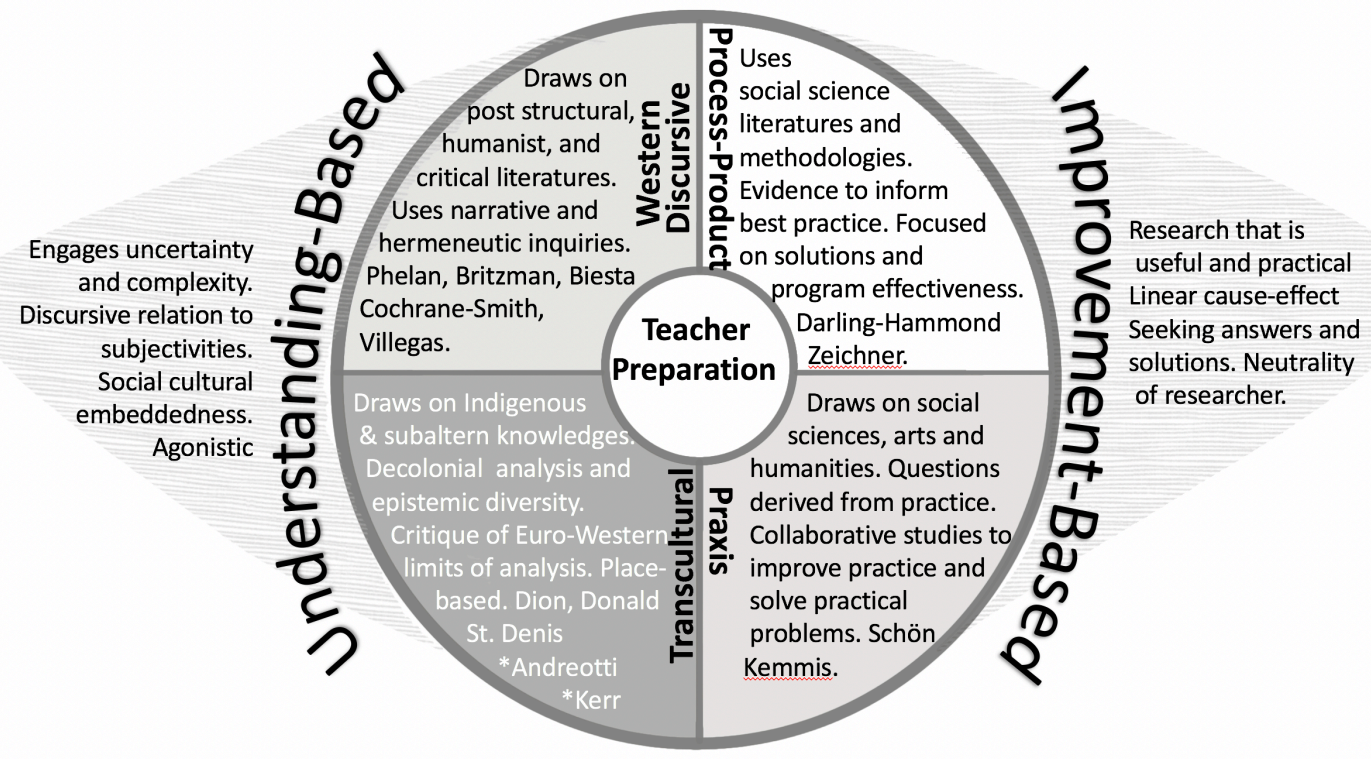

Working with the Cartography

The research projects in teacher education that prompted our engagement with social cartography become more intelligible across research communities when positioned on this social cartography. We discuss these projects here in relation to the cartography to highlight the ways that we imagine the engagement of researchers in teacher education with our own mapping. Our initial research collaboration was a pilot study in a program of teacher education in Canada. The study attempted to map dispositions of teacher candidates in relation to concerns of societal inequalities as they cross geographic, cultural, ideological, emotional and psychological borders through a learning cycle. A subsequent study by Jeannie was a case study of teacher candidates' experience of translating critical ideas from course work into the engaged context of practicum at one elementary school placement (Kerr \& Adamov Ferguson, in press). The engagement with teacher candidates through our research projects was not designed to provide a formula for effective teaching in inequitable educational contexts, but to provide tools for prospective educators to engage in more nuanced understanding of themselves, their responses and affective investments, and the nature of their relations in complex and layered educational contexts.

Both studies engaged the same theoretical framework and overlapped in methodologies. The projects were framed through critical, post-colonial, decolonial and Indigenous informed analyses of modes of dominance in a Settler nation-state. We understand social 
inequalities as emerging in part through the positioning of non-dominant ways of knowing, being and doing as being problematically outside of an unnamed centre of white privilege (Mill, 2007). We think with coloniality scholars, and see that the unnamed and unmarked dominant centre as emerging from long standing structures of colonial domination, in place since the late 1400s, and sourced from Western European traditions of thought and practice (Mignolo, 2011; Grosfoguel, 2007; Wynter, 2003). To work pedagogically within the workshops that were embedded in both projects, we engaged Giroux's (1991) development of "border pedagogy" wherein masked privilege and subordination, that supports institutional and ideological boundary making, are revealed and called into question (pp. 247-252). In this way, we were encouraging what Walter Mignolo (2012) terms border thinking, wherein we encouraged teacher candidates to consider an epistemic orientation that eschews universality of knowing and being in the world, and seeks to promote understanding and awareness across multiple borders created through colonial dominance.

In the design of pre- and post-placement surveys, we attended to multiple forms of inequalities as experienced by the human and more-than-human and that manifest in educational contexts. We focused on inequalities related to cultural affiliations; modes of knowledge practices; differential participation in relation to nation-state authorities; access and affinity within dominant economic systems; and relations to the more-thanhuman and to ecosystems. For example, participants were asked to respond to educational scenarios wherein a child identifiable through their experience of inequality poses a question to them as teachers. Our priorities and desires related to a deep recognition that understanding complex and longstanding concerns requires more than the resources of any one tradition of thought and practice. We focused on a transcultural approach to understanding inequality through epistemic recognition. As a result, we engaged with our priorities through looking to scholarly work emerging from Indigenous peoples, communities and territories. We felt this scholarship was able to recognize the dimensions of colonial forms of continued dominance, and also provide expansive ontological possibilities through prioritizing interconnectivity; relational ethics; and embodied-material possibilities that exceed language.

Our data analysis on both projects similarly drew on a decolonial and critical framework centring the core concepts of autoimmunity (Derrida, 2005), willful ignorance (Alcoff, 2007) and enlightenment epistemology (Mignolo, 2011, 2012; Grosfoguel 2007, 2008). Our interpretations of the concepts are based on elaborations by Jacques Derrida, Linda Alcoff, and Walter Mignolo/Ramón Grosfoguel respectively. Collectively, these theorists link our work to the literatures of anti-racism, decoloniality, critical theory, and whiteness studies. We elaborate these ideas into our place-based location of our study in Canada through then drawing on specific authors problematizing dominant Canadian narratives: Dwayne Donald (2012) settler narratives and colonial logics; Vanessa Andreotti (2011, 2012, 2015), Jeannie Kerr $(2014 ; 2019)$ and Jeannie Kerr and Amy Parent (2015) objective knowing in education; Eva Mackey (2002) and Verna St. Denis (2011) multicultural innocence and benevolence; and Sunera Thobani (2007) exalted subjectivities. Each provides a critique and analysis of modes of dominance in

Journal of Contemporary Issues in Education, 2020, 15(2), pp. 69-84. 
contemporary democratic Canadian society. A more extended discussion of our research projects and theoretical framework for data analysis is provided in articles specific to the research projects (Kerr \& Andreotti, 2019; Kerr \& Adamov Ferguson, in press).

The priorities of our research studies and analyses emphasize understanding and decolonial engagement, and positions our research quite clearly (for us) on the transcultural dimension of our cartography. Our emphasis on examining the complexities of the challenges of working with teacher candidates as they cross multiple forms of borders, positions our work on the left side of the cartography. Similarly, our concern with subjectivities and critical theory also positions us to the left of the cartography. We are not specifically trying to achieve the most optimal learning cycle for teacher candidates and measure its effectiveness. We are considering how offering certain frames of reference from within the learning cycle through experiences and a meta language, may in fact help us face the complexities of how teacher candidates might be engaging with otherness in ways that would complicate our work - as opposed to looking for examples to celebrate the fact that they are doing what we expect them to do. As researchers, we share the affinity of engaging with modes of understanding our work in teacher education with a focus on subjectivities, discursive constraints and subjective location.

There is another movement offered through the cartography that distinguishes between scholars that are similarly focused on understanding based on differing affiliations, priorities and desires. As stated earlier, we see Phelan's (2011) "fourth phase" teacher education scholarship as attending inter-disciplinarily to subjectivities of people in multilayered, complex educational contexts, but with a particular attention to the discursive productions of teaching identities, school practices and social values (pp. 214-217). We share these similar priorities yet differ in some key areas. As stated earlier, our priorities, desires and affiliations extend to a commitment to scholarship and research that embraces Mignolo's border thinking through being transparent about epistemic locations in relation to power, and a thoughtful engagement with multiple and silenced epistemic traditions. We particularly observe our priorities of social equality in education, and acknowledge that particular epistemologies emerging from Indigenous peoples, communities and lands have traditionally been silenced through colonial structures via Eurocentric knowledge practices that position knowledge emerging from the West as unlocated, abstract and having universal worth. Thus, we prioritize engaging with critical theory beyond the West. Following Catherine Walsh (2012), and her identification of the geo-politics of critical thought, we seek to engage with critical thought that is self-conscious of its relation to power.

This elaboration of our research project and positioning on the map is meant to highlight the ways the cartography might be used to generate understandings across paradigms of scholarship that inform teacher education research focused on diversities (or difference) and inequalities. Our decolonial, postcolonial and Indigenous informed priorities are often unfamiliar to other researchers in teacher education, and we hope the elaboration in this section provides some increased understanding. Although, this is a sketch of the 
projects and priorities, and more detailed work on the studies are provided in other publications (Kerr \& Andreotti, 2018, 2019; Kerr \& Adamov Ferguson, in press). Importantly, the elaboration is not meant to convince others that our approach is superior and should be followed. We see great benefit in multiple orientations as uncovering certain aspects that might be invisible from other perspectives. We feel that the continued multiplicity of approaches is important and generative, but that we require tools to support intelligibility and understanding. It is our hope that our cartography has contributed to these priorities. The cartography is not meant to be static and defended as is, it is offered as an engagement and a request to reform it to increase greater understanding in the field. It is hoped that our cartography will inspire other researchers to present research in ways that highlights their ideological priorities, assumptions and commitments so as to acknowledge the socio-cultural work we do as researchers and the hope of engaging in important educational concerns across ideological differences.

\section{Conclusion}

This article was prompted by a desire for research in teacher education to be more selfaware of its social-cultural commitments and assumptions and historical context to enable generative sharing and dialogue across research communities. We recognize that researchers are similarly interested in difference or diversities and inequalities in teacher education research, but that paradigmatic assumptions underlying scholarship makes intelligibility of research challenging. Our commitment to understand social inequalities through teacher education research is widely shared, but we argue that to create generative understandings in the field, we require imaginative methodologies that bring greater understanding across what are communities of thought and practice that rely on different epistemic and ontological assumptions. With this in mind, we engaged with Paulston's social cartography methodology to provide a venue where researchers might possibly see each other in relation - without being required to eschew cherished commitments. Our cartography was informed by both Phelan and Cochran-Smith and Villegas who provided generative thought on the socio-cultural aspects and history of teacher education research. We provided our provisional mapping of teacher education research focused on diversities and inequalities in a way we hope has contributed to an understanding of significant priorities, desires and scholarship in the socio-cultural work of teacher education research - as we see it. To highlight the use of this cartography we discussed our own research that is based in critical, post-colonial, decolonial and Indigenous theory, and discussed this work in a way that placed our work on the cartography. We invite others to use, change and reform this map with their own understandings. We extend this invitation to researchers in teacher education as a way to connect with each other in more depth of knowledge and understanding. We do so in the hopes of generativity and dialogue in research in teacher education, and also in providing ways to understand and address the reproduction of social inequalities in and through teacher education.

\section{References}

Journal of Contemporary Issues in Education, 2020, 15(2), pp. 69-84. (c) Author(s), Creative Commons Attribution 4.0 (CC BY 4.0) licence http://ejournals.library.ualberta.ca/index.php/JCIE

doi 10.20355/jcie29423 
Alcoff, L. M. (2007). Epistemologies of ignorance: Three types. In S. Sullivan and N. Tuana (Eds.), Race and epistemologies of ignorance (pp. 39-58). New York: State University of New York Press.

Amsler, S., Kerr, J., \& Andreotti, V. (2020). Interculturality in teacher education in times of unprecedented global challenges. Education and Society, 38(1), 13-37. https://doi.org.10.7459/es/38.1.02

Andreotti, V. (2011). (Towards) decoloniality and diversality in global citizenship education. Globalisation, Societies and Education, 9(3-4), 381-397. https://doi.org.10.1080/14767724.2011.605323

Andreotti, V. (2012). Education, knowledge and the righting of wrongs. Other Education: The Journal of Educational Alternatives, 1(1), 19-31. https://doi.org.10.1163/9789463007290_009

Andreotti, V. (2015). Post-colonial perspectives in research on higher education for sustainable development. In M. Barth, G. Michelsen, M. Rieckmann, \& I. Thomas (Eds.), Routledge handbook of higher education for sustainable development (pp. 194206). New York: Routledge.

Andreotti, V. (2016). Research and pedagogical notes: The educational challenges of imagining the world differently. Canadian Journal of Development Studies, 37(1), 101-112. https://doi:10.1080/02255189.2016.1134456

Andreotti, V., \& Pashby, K. (2013). Digital democracy and global citizenship education: Mutually compatible or mutually complicit? The Educational Forum 77(4), 422-437. https://doi.org.10.1080/00131725.2013.822043

Andreotti, V., Stein, S., Pashby, K., \& Nicolson, M. (2016). Social cartographies as performative devices in research on higher education. Higher Education Research \& Development, 35(1), 84-99.

Bhabha, H. (1994). The location of culture. New York: Routledge.

Cochran-Smith, S., \& Villegas, M.A. (2015). Framing teacher preparation research: An overview of the field, part I. Journal of Teacher Education, 66(1) 7-20. https://doi.org.10.1177/0022487114549072

Cochran-Smith, S., Villegas, M.A., Abrams, L., Chavez-Moreno, L., Mills, T., and Stern, R. (2015). Critiquing teacher preparation research: An overview of the field, part II. Journal of Teacher Education, 66(2), 109-121. https://doi.org.10.1177/0022487114558268

Derrida, J. (2005). Rogues: Two essays on reason. Translated by Pascal-Anne Brault and Michael Naas. Stanford: Stanford University Press.

Donald, D. (2012). Forts, colonial frontier logics, and Aboriginal-Canadian relations: Imagining decolonizing educational philosophies in Canadian contexts. In A. A. Abdi (Ed.), Decolonizing philosophies of education (pp. 91-111). Rotterdam: Sense Publishers.

Giroux, H.A. (1991). Postmodernism as border pedagogy: Redefining the boundaries of race and ethnicity. In H. Giroux (Ed.), Postmodernism, feminism, and cultural politics: Redrawing educational boundaries (pp. 217-256). New York: State University of New York Press.

Grosfoguel, R. (2007). The epistemic decolonial turn. Cultural Studies, 21(2-3), 211-223. https://doi.org.10.1080/09502380601162514

Journal of Contemporary Issues in Education, 2020, 15(2), pp. 69-84. (c) Author(s), Creative Commons Attribution 4.0 (CC BY 4.0) licence http://ejournals.library.ualberta.ca/index.php/JCIE

doi 10.20355/jcie29423 
Grosfoguel, R. (2008). Decolonizing political economy and post-colonial studies: Transmodernity, border thinking, and global community. Eurozine. Retrieved April 23, 2012 from: http://www.eurozine.com/articles/2008-07-04-grosfoguel-en.pdf

Kerr, J. (2014). Western epistemic dominance and colonial structures: Considerations for thought and practice in programs of teacher education. Decolonization: Indigeneity, Education \& Society, 3(2), 83-104.

Kerr, J. (2019). Indigenous education in higher education in Canada: Settler re-education through new materialist theory. In C.A.Taylor \& A. Bayley (Eds.), Posthumanism in higher education: Reimagining pedagogy, practice and research (pp. 313-328). Palgrave MacMillan.

Kerr, J., \& Adamov Ferguson, K. (in press). Crossing borders in initial teacher education: Supporting translations in the inner-city practicum. Scholar One.

Kerr, J., \& Andreotti, V. (2018). Recognizing more-than-human relations in social justice research: Gesturing towards decolonial possibilities. Issues in Teacher Education, 27(2), 53-67.

Kerr, J., \& Andreotti, V. (2019). Crossing borders in initial teacher education: Mapping dispositions to diversity and inequity. Race Ethnicity and Education, 22(5), 647-665. https://doi.org.10.1080/13613324.2017.1395326

Kerr, J., \& Parent, A. (2015). Being taught by Raven: A story of knowledges in teacher education. Canadian Journal of Native Education. 2015 Special edition on Teacher Education, 38, 62-79.

Mackey, E. (2002). The house of difference: Cultural politics and national identity in Canada. Toronto: University of Toronto Press.

Mignolo, W. D. (2011). The darker side of Western modernity: Global futures, decolonial options. Durham: Duke University Press.

Mignolo, W. D. (2012). Local histories/global designs: Coloniality, subaltern knowledges, and border thinking. Princeton: Princeton University Press.

Mill, C.W. (2007). White ignorance. In S. Sullivan \& N. Tuana (Eds.) Race and epistemologies of ignorance (pp. 13-38). New York: State University of New York Press.

Paulston, R. (2000). A spatial turn in comparative education? Constructing a social cartography of difference. In J. Schriewer (Ed.), Discourse formation in comparative education (pp. 297-354). New York: Peter Lang.

Paulston, R. G. (2009). Mapping comparative education after postmodernity. In R. Cowen \& A.M. Kazamias (Eds.), International handbook of comparative education (pp. 965-990). Dordrecht: Springer.

Paulston, R.G., \& Liebman, M. (1994). An invitation to postmodern social cartography. Comparative Education Review, 38(2), 215-232.

Phelan, A. M. (2011). Towards a complicated conversation: Teacher education and the curriculum turn. Pedagogy, Culture \& Society, 19(2), 207-220. https://doi.org. 10.1080/14681366.2011.582257.

Rust, V. D., \& Kenderes, A. (2011). "Paulston and paradigms". In J. C. Weidman and W. J. Jacobs (Eds.), Beyond the comparative: Advancing theory and its application to practice (pp. 19-29). Boston: Sense Publishers.

Journal of Contemporary Issues in Education, 2020, 15(2), pp. 69-84. 
Spivak, G. (2004). Righting Wrongs. The South Atlantic Quarterly, 103 (2/3) 523-581. https://doi.org.10.1215/15476715-1726189

St. Denis, V. (2011). Silencing Aboriginal curricular content and perspectives through Multiculturalism: 'There are other children here'. Review of Education, Pedagogy, and Cultural Studies, 33(4) 306-317. https://doi.org.10.1080/10714413.2011.597638

Suša, R., \& de Oliveira Andreotti, V. (2019). Social cartography in educational research. In Oxford Research Encyclopedia of Education. https://doi.org.10.1093/acrefore/9780190264093.013.528

Thobani, S. (2007). Exalted subjects: Studies in the making of race and nation in Canada. Toronto: University of Toronto Press.

Walsh, C. (2012). 'Other' knowledges, 'other' critiques: Reflections on the politics and practices of philosophy and decoloniality in the 'other' America. Transmodernity, 1(3), 11-27.

Wynter, S. (2003). Unsettling the coloniality of being/power/truth/freedom: Towards the human, after man, its overrepresentation - an argument. CR: The New Centennial Review, 3(3), Fall, 257-237. https://doi.org/10.1353/ncr.2004.0015

Journal of Contemporary Issues in Education, 2020, 15(2), pp. 69-84. 